\title{
Scientific Development Strategy of Adult Education Research in China during the Period of Transition
}

\author{
H.J XING \\ Jilin Construction University, Changchun, Jilin, China
}

\begin{abstract}
The transformation of adult education, is an urgent need to deepen the reform, the scientific development. The paper from recognizing and meet the needs of the "six" the positive point of view, explains the current of problems existing in the adult education in our country, and accordingly puts forward the adult education school subject to promote adult education the four major strategy about the development of science. KEYWORD: Adult education; Transformation period; The scientific development
\end{abstract}

Here "transitional period" refers to the adult education in our country from the traditional to the modern the important transition period. And scientific development is said this period of adult education is neither "on track", as in previous years "Let it go", such as in recent years. But to enthusiasm to face the world trend, rejuvenation and development of education itself three big challenges, calm thinking the negative factor which restricts the healthy development of adult education in our country in a positive attitude to seek solutions from the Angle of the law of education level, win the adult education with the scientific development of vigor, the prestige and status.

\section{ACHIEVEMENT OF ADULT EDUCATION IN OUR COUNTRY AND DISSOLUTION OF THE ADVERSE FACTORS OF "SIX NEEDS"}

The founding of new China, especially since the third plenary session of the eleventh, adult education in our country have made remarkable progress: One is initially formed a for the adults, from literacy to university to continue education system after system of adult education. Another is created in accordance with China's economic and social characteristics of continue education management system and operational mechanism. The third is through training specifications, large quantities of talents, effectively promote the civilization and spiritual civilization in our country's development, greatly enriched the education serve the socialist modernization of content, method and way. The fourth is to improve the spread of the concept of adult education and the concept of updating, for the further development of adult education

\subsection{Know need to increase}

It is about the importance of adult education, focuses on the concept to set up the big education and deepen the understanding of the learning society. But more important, it's to be by making these knowledge from education to the social from all walks of life. From the education of leading cadres to cadres at various levels and from some people to all the people should have profound knowledge. Second, understanding of adult education scientific, specific for each adult education workers, to study the characteristics of adult education, summarizes the law of adult education to explore with Chinese characteristics of adult education, so as to improve the level of adult education in our country.

\subsection{Structure optimization}

Adult education classes, administrative levels, the situation, ways and targets of diversification, reflects its features and advantages relative to the general education. However, the complexity of its internal relations and the overall structure, is also a "doubleedged sword" handle. For healthy and orderly development of adult education in China, in addition to the countries need to adult education across the country for the overall design and the macroeconomic regulation and control, also need our each university adult education college of resource sharing, complementary advantages and common progress. 


\subsection{Model needs to innovation}

Since education produces, human have been from pure language teaching mode transmission to text transmission, electronic technology and several stages, and the ordinary full-time education, broadcasting television education, network education and other education teaching mode. The enrichment of teaching means and with the two results: One is for the learners, learning methods more flexible. The second is the teaching process more complicated. Therefore, through the innovation education mode to realize all kinds of information transmission means and the complementary advantages of education technology, for those who are in adverse conditions ----especially those living in the vast rural and remote areas, ethnic minority areas of learners create convenient conditions of autonomous learning, lifelong learning.

\subsection{Management need to strengthen}

Any education is a targeted, planned and organized mass activities. The dispersion of adult education, adult education teaching activities of the organization and management to increase the difficulty. To guarantee the sustainable and healthy development of adult education, the following three aspects. The management function must be strengthened: One is the country and the education management departments at all levels to improve the adult education policies and regulations system as soon as possible, to strengthen macro-control. Second, school principals and education colleges and universities should follow the intrinsic patterns of education activities, strict process management of adult education teaching. Third, give full play to the social assessment, national supervision, establish the authority of evaluation institutions, improve the adult education quality guarantee system and operation mechanism.

\section{5 "Two wind" need to correct}

Here "the wind", one is the school teaching, a student is in terms of style. Adult education is onthe-job, amateur, dispersion, independent learning activities. For teaching and learning difficulties. In the aspect of teaching, quality consciousness, the economic interests of the drive and to the work of irresponsible, also led to some units not serious implementation of teaching plans, to cut corners. Two mistakes ethos, weakening the function of adult education, to a certain extent, distorted the image of adult education, undermined the credibility of adult education, caused some brands of adult education colleges and universities "can't", if not his "awkward situation. Therefore," the wind ", strengthen management is the main tasks we face.

\subsection{Quality need to improve}

The quality of measuring the current adult education school, must and will cause a dispute. I think that the judgment of the quality of adult education schools is not the standard how to see (for adult education itself many specifications, many standard), but in the actual effect, is that the adult education learners except the diploma, what things can make its lifelong benefit.

\section{THROUGH RUNNING SUBJECT TO PROMOTE THE FOUR STRATEGIES OF ADULT EDUCATION SCIENCE DEVELOPMENT}

The above six aspects need (or problems), and our adult education school reform and development are closely related, what shall we do? From the national situation, regional characteristics, and the school actual conditions, we think that should do the following four aspects.

\subsection{The development of adult education in our country at present stage}

According to the national education career development plan and talk about leadership and focus for the development of adult education in our country at present stage can be summarized as "two innovation", "outstanding two teaching focus", "advance four big training".

Insist on two innovation. According to ", the new stage in the new period our country economy and social development and adult learning needs, and grasp the characteristics and regularity of two needs, the innovation of adult education and development pattern of school running characteristics, grasp the overall trend in the development of adult education in school development initiative.

"Two teaching focus". One is mainly rural adult education, in order to "rural practical talent training project" and "national rural labor force ?

\subsection{How to determine their own school-running features}

From the above for a period of adult education development in our key consideration, we can form their own school-running features from the following three aspects:

First is to consolidate the achievements. In general, the school professional category, advantages and main service industry or field, also is the advantage of adult education field, such as medicine, normal, finance, construction and other colleges and universities, they both industry advantage, has the massive history and social impact.

Second, the new brilliance. For key national 
development, and can not exclusive monopoly of the field, with associated with the university's interdisciplinary or emerging as the breakthrough point into the bold, expand new areas can expand the scope of services and social impact, and can use the practical advantages of adult education promote the subject construction of general education, is a long term development strategy.

Third, more competitive. In today's rapid development of science and technology, competition in the market economy mechanism, "a man without I have," the development idea of "people have me fine" will become the key to victory.

\section{PROMOTING DEVELOPMENT BY INNOVATION}

The thought of lifelong education, the concept of people-oriented, the application of information technology is to promote the development of adult education transformation three basic elements, therefore, with the reform to promote transformation, realize development with innovation, are the age characteristics of adult education. Concrete should from the following several aspects.

\subsection{Innovative teaching mode}

The modern network multimedia technology is applied to adult education's teaching process, through a variety of teaching media integration and complementary advantages, build to media process of pluralistic, open and flexible, autonomous, which features suitable for students under various conditions of continuous learning teaching mode.

\subsection{Optimizing the teaching content}

According to the needs of different groups, to establish different module of learning content, through a broad education resources to meet the individualized needs of students. Through the cross combination of record of formal schooling education, non-academic education content, improve the comprehensive quality of people and the harmonious development of man and society.

\subsection{Activate the measures for the administration of setting up the "people-oriented" management concept}

Strengthening the management of adult education teaching and the sense of service, adhere to the concept of administering education according to law safeguard education as the basic law of scientific activities, implementing credit system management, for the students to create "learning what they need, solve the difficult, to do their best, have learned something" autonomous learning, lifelong learning atmosphere.

\section{WITH QUALITY OF CASTING BRAND}

The advantage of the brand market competition, and talent cultivation is the quality of life. With the talent training quality, therefore, casting brand of adult education, is the reform and development of adult education in the new period of long-term goals and direction. The influencing factors on the quality of the adult education in our country at present basically has: is a guiding ideology is not correct, some vocational colleges pay attention to economic ignore social benefits. Secondly, a significant number of students learning motivation is not pure, heavy degree light ability. Three is the national macroeconomic regulation and control of adult education, quality supervision and evaluation system is not established. To completely solve these problems though needs a long-term process, this needs us from starts from me, start from now, and give special attention to in the following three aspects: One is to firmly establish the idea of "quality for this", strengthen to the students to social sense of mission, the sense of honor of adult education. Employing mechanism in our country today has ability to tilt the scales, have diploma level, make learners not only a waste of time and money, also lost to space and development opportunities. Second is based on the lifelong education idea, to the development of social economic development and people's positive interaction, design suitable for different groups, different education goal of diversity training goal and the corresponding process, with the demand of gravity and the joy of success, let the development of the adult education process to become a man, Third, increasing investment, choose and employ persons, goods, content of the basic investment, guarantee the adult education scientific development, with an opportunity of The Times.

\section{REFERENCES}

[1] Wang, J.P.2008. Vocational and Adult Education Development and Policy Direction. Journal of Vocational and Adult Colleges and Universities the Headmaster Lectures, Workshops. (10): 19

[2] Yan.,J.C. 2008. Remote Leaned Slightly and Continuing Education Reform and Development. Journal of Vocational and Adult Colleges and Universities the Headmaster Lectures, Workshops. (10): 21 